\section{First report of Angiostrongylus cantonensis in Porto Alegre, State of Rio Grande do Sul, Southern Brazil}

\author{
Bianca Barbieri Cognato ${ }^{[1]}$, \\ Alessandra Loureiro Morassutti ${ }^{[1]}$, \\ Ana Cristina Aramburu da Silva ${ }^{[1]}$ \\ and Carlos Graeff-Teixeira ${ }^{[2]}$
}

[1]. Laboratório de Biologia Parasitária, Faculdade de Biociências, Instituto de Pesquisas Biomédicas, Pontifícia Universidade Católica do Rio Grande do Sul, Porto Alegre, RS. [2]. Laboratório de Parasitologia Molecular, Instituto de Pesquisas Biomédicas, Pontifícia Universidade Católica do Rio Grande do Sul, Porto Alegre, RS.

Address: Dr ${ }^{\mathrm{a}}$ Bianca Barbieri Cognato. Laboratório de Biologia Parasitária/ Faculdade de Biociências/Instituto de Pesquisas Biomédicas/PUCRS. Av. Ipiranga 6690, 90690-900 Porto Alegre, RS, Brasil.

Phone: 5551 3320-3500 extension: 4144; Fax: 5551 3320-3568

e-mail: bicognato@hotmail.com

Received 15 April 2013

Accepted 27 June 2013

\section{Dear Editor,}

Angiostrongylus cantonensis is a lungworm found in rats (mainly Rattus norvegicus) and is the main etiologic agent of eosinophilic meningitis after accidental human infection. Parasitological diagnosis is difficult because larvae are seldom found during cerebrospinal fluid examinations; molecular methods are thus required. According to Wang et al. ${ }^{1}$, more than 2,820 cases have been reported in approximately 30 countries, mostly in Asia and the Pacific Islands. A. cantonensis infection has been increasingly detected in travelers returning from endemic areas ${ }^{2}$ and is now considered to be a growing food safety concern ${ }^{3}$. Laboratory isolation and identification of this parasite were reported for the first time in Brazil in the State of Espírito Santo after eosinophilic meningitis was diagnosed in two patients ${ }^{4}$, followed by its detection in two patients in Pernambuco ${ }^{5}$. A. cantonensis larvae and adult worms or their deoxyribonucleic acid (DNA) have been detected in hosts from several coastal locations in Brazil, ranging from Pará in the north to Santa Catarina in the south ${ }^{6-8}$. However, A. cantonensis was not found in Rio Grande do Sul ${ }^{9}$. While trying to isolate larvae of Strongyloides ratti and $S$. venezuelensis in an investigation of antigens that are cross-reactive with $A$. costaricensis, a rat $(R$. norvegicus) was captured in Vila Fátima, Porto Alegre, Brazil $\left(30^{\circ}\right.$ 2' 53.99" S 519' 30.69" W). The animal was kept alive for the collection of larvae from its feces. The animal died several hours after capture, and necropsy was performed. The lungs showed several areas with white, hard and consolidated lesions that were removed and analyzed under a stereomicroscope. Eleven female and two male worms were found in the pulmonary arteries. The worms were clarified with creosote and mounted on slides for examination under an optical microscope. The morphology of the males' copulatory bursa (Figure 1) and the average length of the worms (females, $26.8 \pm 2.41 \mathrm{~mm}$; males, $20 \pm 1.41 \mathrm{~mm}$ ) were in accordance with data from the literature ${ }^{10}$. A real-time polymerase chain reaction demonstrated a similarity in cycle thresholds (CTs) between DNA sequences from the worms $(\mathrm{CT}=12)$ and from the Akita strain of $A$. cantonensis $(\mathrm{CT}=8)$. A . cantonensis most likely entered Brazil on cargo ships from endemic areas carrying infected rats or an intermediate host ${ }^{11}$. Porto Alegre is a commercial port city on the Guaíba River to which ships deliver many products, such as fertilizers, soybeans and salt, from many parts of the world, including India, Egypt, China and other areas of Brazil. Other Brazilian locations in which the presence of $A$. cantonensis has been reported are also in or adjacent to harbors, indicating that dispersion of the nematode may be occurring through rats on ships. Vila Fátima is approximately $11 \mathrm{~km}$ from the Guaíba harbor and is linked to the port by a stream, Arroio Dilúvio, that is also partially linked to the wastepipe effluent system, which provides a natural habitat and pathway for rats. Although raw mollusks are not typically consumed in Brazil, currently available data indicate that sanitary education and epidemiological surveillance must be urgently updated. The increasing global transit of people and goods is rapidly changing the distribution pattern of infectious agents, such as $A$. cantonensis.
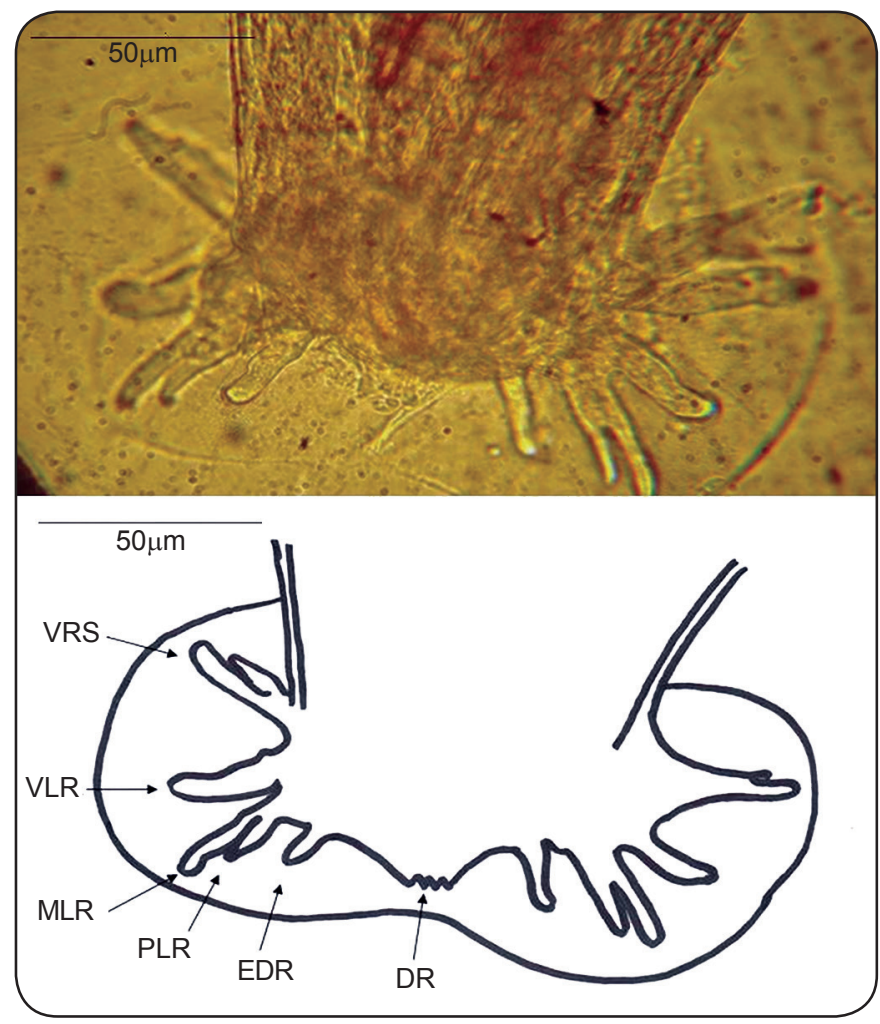

FIGURE 1 - Adult worms detected in the pulmonary arteries of a rat in Porto Alegre, Southern Brazil. A) Ventral image and B) drawing of a male worm's copulatory bursa, indicating the bursal rays. VRS: ventral; VLR: ventrolateral; MLR: mediolateral; PLR: posterolateral; EDR: externolateral; DR: dorsal. 


\section{FINANCIAL SUPPORT}

This study was supported by CNPq, CAPES and FAPERGS.

\section{CONFLICT OF INTEREST}

The authors declare that there is no conflict of interest.

\section{REFERENCES}

1. Wang QP, Lai DH, Zhu XQ, Chen XG, Lun ZR. Human angiostrongyliasis. Lancet Infect Dis 2008; 8:621-630.

2. Slom TJ, Cortese MM, Gerber SI, Jones RC, Holtz TH, Lopez AS. An outbreak of eosinophilic meningitis caused by Angiostrongylus cantonensis in travallers returning from the Caribbean. N Engl J Med 2002; 346: 668-675.

3. Qvarnstrom Y, Silva ACA, Teem JL, Hollingsworth R, Bishop H, Graeff-Teixeira C. Improved detection of Angiostrongylus cantonensis in mollusks and other environmental samples with a specie-specific internal transcribed spacer 1-based TaqMan assay. Appl Environ Microbiol 2010; 76:5287-5289.

4. Caldeira RL, Mendonça CLGF, Goveia CO, Lenzi HL, Graeff-Teixeira C, Lima WS. First record of molluses naturally infected with Angiostrongylus cantonensis (Chen, 1935) (Nematoda: Metastrongylidae) in Brazil. Mem Inst Oswaldo Cruz 2007; 102:887-889.

5. Lima ARMC, Mesquita SD, Santos SS, Aquino ERP, Rosa LRS, Duarte FS. Alicata Disease: neuroinfestation by Angiostrongylus cantonensis in Recife, Pernambuco, Brazil. Alicata Disease 2009; 67:1093-1096.

6. Teles HMS, Vaz JF, Fontes LR, Domingos MF. Registro de Achatina fulica Bowdich, 1822 (Mollusca, Gastropoda) no Brasil: caramujo hospedeiro intermediário da angiostrongilíase. Rev Saude Publica 1997; 31: 310-312.

7. Neuhauss E, Fitarelli M, Romanzini J, Graeff-Teixeira C. Low susceptibility of Achatina fulica from Brazil to infection with Angiostrongylus costaricensis and A. cantonensis. Mem Inst Oswaldo Cruz 2007; 102: 49-52.

8. Simões RO, Monteiro FA, Sánchez E, Thiengo SC, Garcia JS, Costa-Neto SF. Endemic angiostrongyliasis, Rio de Janeiro, Brazil. Emerg Inf Dis 2011; 17:1331-1333.

9. Carvalho OS, Scholte RG, Mendonça CL, Passos LK, Caldeira RL. Angiostrongylus cantonensis (Nematode: Metastrongyloidea) in molluses from harbour áreas in Brazil. Mem Int Oswaldo Cruz 2012; 107:740-746.

10. Maldonado AJ, Simões RO, Oliveira APM, Mott EM, Fernandez MA, Pereira ZM. First report of Angiostrongylus cantonensis (Nematode: Metastrongylidae) in Achatina fulica (Mollusca: Gastropoda) from Southeast and South Brazil. Mem Inst Oswaldo Cruz 2010; 105: 938-941.

11. Graeff-Teixeira C. Expansion of Achatina fulica in Brazil and potential increased risk for angiostrongyliasis. Trans R Soc Trop Med Hyg 2007; 101:743-744. 